\title{
Menelusuri Literatur-Historis Desa di Indonesia: Pola dari Pemukiman Seadanya menjadi Pemukiman Se-barunya
}

\author{
Nurkhalis ${ }^{1}$ dan Nodi Marefanda ${ }^{2}$ \\ ${ }^{1}$ Dosen Prodi Ilmu Sosiologi FISIP Universitas Teuku Umar \\ nurkhalis@utu.ac.id \\ ${ }^{2}$ Dosen Prodi Administrasi Negara FISIP Universitas Teuku Umar \\ nodymarefanda@gmail.com
}

\begin{abstract}
Rural settlements are the history of the origin for some people even nearly reached the total for the life of Indonesian citizens. So much can be known in naming various villages in Indonesia; gampong, kampung, nagari, and so on. The settlement will be an interesting story that was started from portion of the issue of welfare, livelihoods, even re-survival after a bit of social upheavals and natural disasters. This paper will explore further the conditions are at two moment; past and present. Although it is not representative of the overall condition of the countryside in Indonesia, the author hopes this article become a representation when discuss what, why and how are the rural.
\end{abstract}

Keywords : history, village, settlements, rural settlements 


\section{PENDAHULUAN}

Dalam memahami kebutuhan manusia, maka sudah barang tentu dihadapkan pada tiga kebutuha mendasar di antaranya, apa yang disebut dengan kebutuhan Primer seperti sandang, pangan dan papan. Selain itu ada kebuttuhan sekunder (tambahan) seperti alat telekomunikasi informasi, sepeda, kendaraan bermotor. Dan lainnya, kebutuhan Tersier (mewah) merupakan kebutuhan yang memiliki nilai berharga seperti mobil, apartemen, mini market atau swalayan dan barang bernilai materi tinggi lainnya.

Beberapa ilmuwan lainnya, justru membagi dengan perspektif berbeda berkaitan dengan kebutuhan manusia. Misalkan Abraham Maslow, ilmuwan sosial membagi bahwa kebutuhan manusia terdiri dari kebutuhan Fisiologis, Kebutuhan Sosial, keamanan, kebutuhan perhargaan diri dan kebutuhan aktualisasi diri. Terlepas dari perbedaan pemikiran tentang kebutuhan itu, tetapi yang perlu diketahui bahwa kebutuhan papan (tempat tinggal) menjadi hal utama bagi mereka (termasuk bukan golongan ilmuwan sekalipun) sangat perlu untuk dimiliki.

Tulisan ini, akan mencoba mengupas lebih jauh perihal apa yang dinamakan tempat tinggal menjadi bukan saja persinggahan manusia, namun lebih kepada tempat keberlanjutan generasi manusia (beragam kegiatan individu, sosial dan religi berlangsung di sana) bahkan bisa menjadi tempat berkehidupanya dua makhluk hidup selain manusia itu sendiri, yakni hewan atau binatang dan tumbuhan. Adapaun tempat tinggal dalam kajian sosial klasik dinamakan dengan pemukiman. Sedangkan berganti pada kajian sosial modern akan mengalami perbedaan disebut dengan pedesaan. Tiada polemik berarti atas penyebutan keduanya, yang jelas apapun keduanya masih tetap menegaskan tempat bernaungnya manusia.

Secara garis besar, munculnya pemukiman yang berasal dari didirikannya pemukiman untuk dialokasikan kepada suatu kelompok masyarakat. Dimana kehidupannya semula berpindah-pindah (nomaden) sehingga dari situasi dan kondisi tersebut didirikanlah pemukiman agar masyarakat dapat menetap secara permanen. Namun, adakalanya terdapat pemukiman yang dibangun atas pertimbangan atau perhatian pemerintah kepada masyarakat korban bencana sosial baik bencana alam dan konflik dengan membangun pemukiman kembali (resettlemet) demi keberlangsungan hidup mereka. ${ }^{1}$ Adapun tulisan bertujuan untuk mengetahui bagaimana sejarah awal pemukiman desa hingga ke kawasan Aceh dan apa saja penelitian terkait kondisi pedesaan di Indonesia.

\section{TINJAUAN PUSTAKA}

\section{Sejarah Pemukiman Pedesaan di Indonesia}

Dalam mencari literatur pemukiman pedesaan yang berada di Indonesia, maka dimungkinkan kita akan kembali merujuk pada berbagai karangan buku yang dituliskan pada tahun 1980 sampai dengan tahun 1990. Dikarenakan terlalu minimnya literatur yang membahas pemukiman desa. Dan jika pun tanpa ada banyak perbaharuan materi dari suatu buku yang seketika diterbitkan bahkan yang seringkali terjadi hanya mengulang-ulang referensi lama yang telah ada di buku terdahulu.

1Bahrein T. Sugihen, Sosiologi Pedesaan, (Jakarta: RajaGrafindo Persada, 1996), hal. 81 
Meskipun demikian minim rujukan, tidak akan menghilangkan esensi ketika akan berbicara tentang pemukiman di suatu desa di Indonesia.

Ketika mengungkapkan sejarah pemukiman desa, maka ada baiknya menguraikan secara terpisah antara makna pemukiman itu sendiri dan desa. Menurut Undang-undang No. 4 tahun 1992 tentang perumahan dan pemukiman atau permukiman, adalah bagian dari lingkungan hidup di luar kawasan lindung, baik yang berupa kawasan perkotaan maupun pedesaan yang berfungsi sebagai lingkungan tempat tinggal atau lingkungan hunian dan tempat kegiatan yang mendukung perikehidupan dan penghidupan. ${ }^{2}$

Pemukiman dapat dipahami sebagai suatu daerah yang dijadikan oleh (dari) sekelompok orang sebagai tempat tinggal. Dari tempat tersebut penghuninya pergi bekerja mencari nafkah untuk memenuhi kebutuhan hasrat dan kebutuhan hidup. Pemukiman mempunyai beraneka ragam bentuk atau pola sesuai dengan kondisi lingkungan, sistem sosial yang berlaku, dan kebutuhan. Dengan bahasa lain, pola pemukiman ini ditentukan oleh karakteristik yang khas seperti faktor geografik (lembah, bukit, pinggir sungai, gurun, dataran berpadang rumput, pinggir laut atau pantai dan sebagainya), faktor sosial (sistem pertanian seperti sedenter/ sengkedan/ terastering-yang bermukaan tanahnya berundak-undak, berpindah-pindah, kekeluargaan, dan lain-lain), disamping sistem kepercayaan yang dianut para pemukim. ${ }^{3}$

Pemukiman yang terbentuk pada daerah pedesaan cenderung membentuk pola pemukiman agraris, hal ini berkaitan dengan struktur pekerjaaan dan aktivitas penduduknya yang kebanyakan di bidang pertanian sehingga mempengaruhi pola pemukimannya. Secara khusus pola pemukiman agraris terbagi dalam empat macam pola yaitu,

1) Pola pemukiman sarang laba-laba

Adalah pola pemukiman dimana sejumlah kelompok masyarakat bertempat tinggal pada suatu lokasi tertentu secara terkumpul, sedangkan sawah dan ladang mereka di luar lokasi pemukiman.pola pemukiman ini terjadi karena adanya kelompok masyarakat yang membuka perkampungan baru sambil membuka sawah, ladang di sekitarnya. Setelah permukiman itu padat, sebagian kelompok masyarakat mendirikan pemukiman dan sawah serta ladang baru di tempat yang lain.

2) Pola pemukiman sarang lebah

Merupakan bentuk pemukiman dimana sejumlah kelompok masyarakat bertempat tinggal pada masing-masing sawah, ladang atau kebun yang dibukanya. Pemukiman ini terjadi karena ada sekelompok masyarakat yang membuka areal lahan pertanian di sekitar tempat tinggalnya.

3) Pola pemukiman jalur sungai

Adalah bentuk pemukiman dimana sejumlah kelompok masyarakat bermukim di sepanjang jalur sungai. Mereka juga membuka sawah dan ladang di sekitar tempat tinggal dengan harapan bisa memadai pasokan air bagi apa yang ditanami.

2 Budi Fathony, Pola Pemukiman Masyarakat Madura di pegunungan Buring, (Malang: Cita Intrans Selaras, 2009), hal. 12

${ }^{3}$ Opcit..., hal. 71 
4) Pola pemukiman jalur pantai

Sebagai bentuk pemukiman dimana sejumlah kelompok masyarakat bermukim sepanjang pantai. Mereka bekerja sebagai nelayan dan juga membuka sawah dan ladang di darat. Pemukiman jenis ini terjadi karena adanya potensi ganda pada suatu masyarakat yang memiliki mata pencaharian selain sebagai nelayan dan juga menjadi petani. ${ }^{4}$

Sedangkan yang dimaksud dengan desa, sebagai bentuk pemukiman dalam suatu daerah yang berada pada posisi di luar batas perkotaan, mempunyai bentuk yang berbeda-beda pula dari satu daerah dengan daerah lainnya. Meskipun demikian, dalam karakteristiknya satusama lain secara umum tidak berbeda. Di dalam literatur sosiologi dari kajian lokal dan Indonesia secara utuh, desa mendapat perbedaan atas namanya, misalnya, untuk wilayah Aceh (disebut dengan gampong-beberapa daerahnya bagian menyebut kampung di Aceh Tengah) mukim, nagari (identik namanya bagi wilayah Sulawesi), huta (kuta) di tanah Batak, ada juga penyebutan dengan ranah Minang (sebagaimana orang Minangkabau) dan lain sebagainyatermasuk Indonesia bagian timur juga mempunyai istilah khusus dalam menyebutkan kata desa. ${ }^{5}$

Pada umumnya, suatu pemukiman mempunyai beberapa ciri atau aspek tertentu yang memungkinkan ia berdiri sebagai satu pemukiman yang utuh yang disebut desa. Ciri atau aspek yang dimaksudkan di antaranya:

1) Suatu desa biasanya terdiri dari sekelompok rumah, sejumlah lumbung padi, dan gudang-gudang atau bangunan lain yang dipakai bersama. Dari lahan itu yang dimungkinkan kepemilikan secara sendiri-sendiri atau dimiliki dengan dipakai secara bersama-sama.

2) Di dekat atau disekitar desa biasanya terdapat lahan pekarangan, yang diusahakan dan mungkin dipakai sebagai lahan usaha untuk mendukung kehidupan atau kebutuhan sehari-hari.

3) Lahan usaha tani umumnya terdapat jauh atau terpisah dari pusat pemukiman.

4) Sering pula di sela-sela lahan usaha tani terdapat padang pengembalaan,

5) Di luar ciri yang tersebut di atas, dan mungkin juga sebagai batas alami satu desa dengan desa-desa lain di sekitarnya terdapat hutan semak belukar yang sering pula merupakan sumber energi bagi pemukiman desa. ${ }^{6}$

Dalam banyak penelitian akan dijumpai pengertian pola pemukiman dibatasi pada pola pedesaan. Hal itu dilakukan agar penarikan fokus mengaitkan kajian pemukiman dapat diperoleh secara menyeluruh. Yang jelas, pedesaan menjadi kawasan akan selalu menarik untuk terus diamati sebagai daerah yang kurang lebih perhitungan penduduk sebanyak 2.500 jiwa 47-49

4Jurnal Siti Muriah, Model Pengembangan Desa-desa Wilayah Perbatasan Secara Institut, hal.

5Ibid..., hal. 71-72

${ }^{6}$ Opcit..., hal. 73 


\section{Karakteristik Pemukiman Desa}

Kehidupan orang yang berada di desa, terkesan dengan pembawaan ketradisioanalan diri, menjadi daya tarik tersendiri. Di samping terlihat kerukunan yang terjalin di sana, tidak menutup kemungkinan bahwa desa rentan terjadi konflik dan persaingan, yang apabila dikhusukan mengarah kepada apa yang disebut dengan pertengkaran. Sumber dari banyaknya pertengkaran yang dalam masyarakat pedesaan di Indonesia rupa-rupanya berkisar pada hal tanah, sekitar masalah kedudukan atau gengsi, sekitar hal perkawinan, sekitar hal perbedaan antar kaum tua dan kaum muda dan sekitar perbedaan antara pria dan wanita. ${ }^{7}$

Hal yang tersebut di atas, sangat bersesuain dengan ungkapan Landis dalam Jefta Leibo (ed) atas karyanya berjudul 'Psychological Traits of Farm People', mengenai kecendrungan-kecendrungan psikologis atau kepribadian dari orang-orang desa. Adapun kecendrungan-kecendrungan psikologis itu adalah:

a) Mereka memiliki sifat menentang terhadap orang luar, selanjutnya memiliki sifat rendah hati yang sifat ini sebagai akibat adanya kemiskinan yang dialami atau dengan kata lain mempunyai derajat kemakmuran yang rendah.

b) Adanya sikap otoriter dari orang tua terhadap mereka yang lebih muda umurnya, sehingga akibatnya tidak ada kebebasan untuk mengemukakan pendapat.

c) Adanya kecendrungan bahwa yang dipikirkannya adalah dirinya atau lingkungannnya sendiri (tidak mahu tahu dengan orang lain-orang luar.

d) Adanya sifat konservatisme, di mana sifat ini muncul karena dilihat dari penghidupan pokok, adalah di bidang pertanian dengan resiko alam yang terlalu besar.

e) Mereka sangat toleran dengan nilai-nilai yang dimilikinya, dan sebaliknya in-toleran terhadap nilai-nilai yang dimiliki oleh kelompok lain.

f) Adanya sikap pasrah (terserah pada yang Maha Kuasa) yang mana sangat berbeda dengan sifat manipulasi.

g) Punya sifat udik/ pedalaman, dimana sifat ini sebagai akibat kurangnya kontak dengan dunia luar (kurangnya sarana transportasi dan komunikasi). ${ }^{8}$

Terlepas dari berbagai pernyataan yang menjelaskan karakteristik orang bermukim di desa dalam gambaran yang terkesan negatif. Akan tetapi akan sering pula kita temukan berbagai dimensi positif dari karakteristik mereka. beberapa hal positif itu, di antaranya, pertama, sistem tolong menolong. Ketika diperlukan tambahan bantuan dalam pekerjaan pertanian, tanpa perlu disewa tetapi meminta kepada bantuan kepada warga lain, maka seketika hal tersebut akan terealisasi. Umunya hal tersebut di Indonesia disebut dengan gotong royong.

\footnotetext{
7 Sajogyo \& Pudjiwati Sajogyo, Sosiologi Pedesaan: Kumpulan Bacaan, (Yogyakarta, Gadjah Mada University Press, 2005), hal. 24

8 Jefta Leibo \& J. Nasikun, Sosiologi Pedesaan: Desa kita sebuah Potret Perubahan dalam Berkesinambungan, Mencari suatu Strategi Pembangunan Masyarakat Desa Berparadigma Ganda, (Yogyakarta: Andi Offset, 1986), hal. 3-4
} 
Selanjutnya, memiliki jiwa bermusyawarah, mengenai hal tersebut, bahwa keputusan-keputusan syang diambil dalam rapat-rapat (yang berlangsung di pemukiman desa) tidak berdasarkan mayoritas, yang menganut suatu pendirian tertentu, melainkan seluruh rapat, seolah-olah sebagai suatu badan. ${ }^{9}$ Walaupun dicirikan relatif sederhana (bangunan rumah penduduk di desa umunya jarang atau terpencar), akan ditemukan di dalamnya hubungan antara anggota masyarakatnya intim dari kekerabatan, persaudaraan masih sangat kuat.10

\section{Varian dari Tipologi Desa}

Berbicara lebih jauh dengan ragam tipologi, ada yang menarik dengan apa yang diungkapkan Dirjen Pembangunan Masyarakat Desa Departemen Dalam Negeri, menyatakan bahwa ada beberapa tipologi desa di antaranya,

1) Desa Tradisional (Pra Desa)

Tipe desa semacam ini kebanyakan kita jumpai pada masyarakat suku-suku terasing, di mana seluruh kehidupan masyarakatnya termasuk teknologi berocok tanam, cara-cara pemeliharaan kesehatan, cara-cara memasak makanan dan sebagainya masih sangat bergantung pada pemberian alam sekeliling.

2) Desa Swadaya

Desa ini memiliki kondisi yang relatif statis tradisional, dalam arti masyarakatnya sangat tergantung pada keterampilan dan dan kemampuan pimpinannya. Praktik atau kegiatan masyarakat lebih kepada komando (arahan) dari sang pemimpin. Maju atau tidak akan diperhitungkan dari pengarah nantinya.

3) Desa Desa Swakarya

Keadaan desa ini sudah mulai disentuh oleh atau menjalin hubungan dengan kelompok dari luar, sehingga adanya pembaharuan yang sudah mulai dirasakan oleh angota masyarakat. Benih-benih demokrasi dalam pembangunan sudah mulai tumbuh, artinya sudah tidak lagi semata-mata bergantung pada pemimpin saja.

4) Desa Swasembada

Dalam kondisi desa ini, terlihat bahwa masyarakatnya telah maju, dengan sudah mengenal mekanisme pertanian dan teknologi ilmiah telah mulai digunakan. Pada akhinrya turut membawa pada situasi dan kondisi berkehidupan selalu berubah-ubah sesuai dengan perkembangan zaman.

5) Desa Pancasila

Desa semacam ini merupakan tipe ideal yang dicita-citakan bersama yaitu dengan tercapainya masyarakat adil dan makmur. ${ }^{11}$ Sesuai dengan salah satu ketentuan yang berada pada sila kelima dalam Pancasila sebagai pedoman

${ }^{9}$ Opcit..., hal. 27 dan 31

10 Sapari Imam Asy'ari, Sosiologi Kota dan Desa, (Surabaya, Usaha Nasional, 1993), hal. 101

${ }^{11}$ Opcit..., hal 11-12 
berkehidupan warga negara di Indonesia. Untuk dapat sampai pada sejatinya desa Pancasila maka satu hal yang harus diperhatikan yakni, kepedulian atau kebersamaan.

Desa di Indonesia, berbeda dengan desa-desa di negara lain seperti Eropa, Afrika, Asia atau Amerika dam Australia. Dari letak alaminya desa-desa di Indonesia, secara garis besar dapat dikategorikan sebagai:

a) Desa-desa pantai

Desa ini sangatlah bergantung kepada pantai atau pesisir lautnya. Ada yang berada di pantai yang landai dengan pasir putihnya, ada juga pantai yang berbukitan seperti di pantai selatan pulau Jawa (meskipun tidak semuanya) dan sebagainya.

b) Desa-desa di daratan rendah (Ngare)

Desa ini pada daratan rendah ini bervariasi sesuai dengan sejarah terbentuk dan perkembangan masing-masing. Namun desa-desa seperti ini relative dapat leluasa mengatur pola ruang desa atau teritorialnya dari desa-desa pengunungan atau pantai.

c) Desa-desa di pengunungan

Desa ini akan sangat bergantung kepada keadaan alamnya. Rumah-rumah penduduk desa pengunungan ini sering terlihat bersaf-saf secara hirearkis, di celah-celah perbukitan atau lembah pengunungan, atau di kanan kirinya terdapat sungai.

d) Desa-desa di perkataan atau sekitar kota

Desa yang berada di perkotaan atau sekitar kota, ialah yang termasuk wilayah kota atau perkotaan, dan desa yang sudah memenuhi persyaratan untuk disebut kota.

e) Desa-desa pedalaman

Desa ini yaitu desa-desa yang berada jauh dari kota dan relative terisolir, di wilayah pengunungan atau pedalaman, atau jauh beada di luar kota. ${ }^{12}$

\section{Pola Pemukiman Desa di Aceh}

Sebenarnya sangat terbatas sekali ditemukan literatur yang mengkaji tentang pemukiman di Aceh. Namun, hal tersebut bukanlah menjadi alasan dan kesulitan kronis sehingga menyebabkan minimnya mengangkat bahasan pada penjabaran pola pemukiman yang berlangsung di Aceh. Oleh karena itu, tidak ada salahnya beberapa referensi pendukung dari buku klasik (baik naskah buku ataupun karya penelitian di lapangan) turut menjadi cakupan menggambarkan pola pemukiman desa di Aceh.

Penyebutan pemukiman (desa), tidak pelak ditemukan istilah yang masih digunakan hingga tekini, disebut Gampong di Aceh dan Kampung yang berada di

${ }^{12}$ Opcit..., hal. 102 
wilayah Aceh Tengah.13 Sebagaimana untuk dapat dipahami bahwa ketika akan menggambarkan pemukiman yang keberadaanya terdapat dalam lingkup sebuah desa, maka darinya (desa) dalam hal ini memiliki istilah yang beranekaragam. Mulai dari pembagian administratif Indonesia atas wilayah provinsi, kabupaten, kecamatan dan desa sering menimbulkan kekaburan dalam pengertian masyarakat desa. Bayangkan saja untuk pengertian sosiologi desa di Jawa, berbeda sekali dengan penyebutan nama desa yang ada di Aceh, Padang, Bali, Ambon dan Sulawesi. Besarannya, susunan dan hubungan sosialnya berbeda-beda walaupun beberapa ciri seperti keakraban, tolong-menolong dan keterikatan pada tempat pemukimannya sama. Oleh karena itu, ketika akan menyinggung perihal pola pemukiman di desa, dalam pengertian administratif, akan ditemukan berbagai topografi (bentukan) dari desa, yaitu desa pengunungan, desa daratan rendah, desa daratan tinggi dan pantai. ${ }^{14}$

Apabila semakin fokus pembahasan ini pada sejarah pemukiman yang dikhususkan berada di Aceh, akan didapati hubungan sosial dan budaya di pemukiman dalam lingkup desa. Bagian terbesar dari wilayah pemukiman suku bangsa Aceh merupakan dataran rendah, sedangkan yang lainnya berada pada tanah yang berbukit-bukit. ${ }^{15}$

Berdasarkan penelitian dahulu (telah dibukukan dimungkinkan untuk kebutuhan arsip daerah Aceh), tentang pemukiman (awal disebut kemukiman) di Aceh terbagi dalam dua pembagian besar, pertama, kemukiman Garot dan kemukiman Laut Tawar. Kemukiman Garot terletak memanjang si sebelah timur Krueng Baro, yang merupakan saluran primer untuk pengairan areal persawahan di sekitarnya, kira-kira delapan kilometer di sebelah selatan Sigli, ibu kota kabupaten Pidie. Pemukiman tersebut menampakkan ciri-ciri khas desa sebagai desa pertanian yang padat dan hampir tidak ada bedanya dengan pemukiman-pemukiman pedesaan pedalaman lainnya di kabupaten Pidie. Sedangkan untuk kemukiman Laut Tawar terletak di pesisir selatan danau Laut Tawar, kira-kira delapan kilometer di sebelah timur Takengon, ibu kota kabupaten Aceh Tengah. Keadaan lingkungannya terletak pada daerah tinggi yang berbukit-bukit, dan ditumbuhi oleh hutan lebat serta pinus merkusii. ${ }^{16}$ Kedua kemukiman tersebut sangat mewakilkan ketika akan menggambarkan proses kemunculan pemukiman yang ada di Aceh.

Lain halnya dengan pernyataan Bahrein (1996), dari berbagai pengamatan dan studi terlihat bahwa bentuk desa (baik pola, pengaturan atau organisasi dan tata letak bangunan pemukiman) akan berbeda dari satu daerah dengan ke daerah lain. Agaknya, kondisi alam lingkungan sekitar (geografis) seing mempengaruhi atau menentukan bentuk (tata letak) desa. Seringpula bentuk desa itu berkaitan erat dengan

${ }^{13}$ Irine Hiraswati Gayatri, et al, Runtuhnya gampong-gampong di Aceh, (Jakarta: Pustaka Pelajar, 2008), hal. 4

14 Soediono M. P. Tjondronegoro, Keping-keping Sosiologi dari Pedesaaan, (Jakarta: Direktorat Jenderal Pendidikan Tinggi Departemen Pendidikan dan Kebudayaan, 1999), hal. 1819

${ }^{15}$ Z. Ahmad, et al, Geografi Budaya Daerah Istimewa Aceh, Proyek Penelitian dan Pencatatan Kebudayaan Daerah, (Jakarta: Departemen Pendidikan dan Kebudayaan, 1978), hal. 17

16 Mc Suprapti (ed), Pola Pemukiman Penduduk Pedesaan Daerah Propinsi D. I. Aceh, (Aceh: Departemen Pendidikan dan Kebudayaan Proyek Investaris dan Dokumentasi Kebudayaan Daerah, 1981), hal. 1 dan 7) 
karakteristik sosial dan budaya yang dominan di pemukiman bersangkutan. Desa yang terbentuk dari orang-orang yang masih mempunyai pertalian keluarga lewat perkawinan (cosanguines) seperti gampong di Aceh akan berbeda dengan bentuk kampong (desa) di daerah lain. ${ }^{17}$ Pemukiman biasanya terpusatkan pada satu lokasi, yang terdiri dari sejumlah rumah tempat tinggal, pekarangan, kebun, dikelilingi oleh areal persawahan, dan terbagi menjadi beberapa jurong (lorong). ${ }^{18}$ Pemukiman membentuk suatu klaster dari rumah dimiliki oleh sejumlah keluarga yang masih mempunyai hubungan darah. ${ }^{19}$

Dan seiring dengan kondisi wilayah atau dipengaruhi oleh faktor alam, maka seketika termuncullah apa yang disebut dengan pemukiman baru (resettlement). Seperti apa yang telah diungkapkan awal pada bab ini, dari apa yang disebut pemukiman baru yang lebih digolongkan pada yang menempati ialah orang yang semula mengalami keadaan tranmigrasi (berpindah-pindah), selain itu bisa disebabkan kebijakan pemerintah yang menggusur kawasan di suatu penduduk namun akhirnya menempatkan mereka kembali di suatu tempat yang telah di tentukan. Tidak hanya itu saja, mereka yang akhirnya digolongkan untuk menghuni pemukiman baru juga mereka yang merupakan korban bencana alam, baik itu bencana banjir dan beberapa zona yang telah ditetapkan sebagai daerah rawan.

Perlu untuk diketahui, bahwa menetapkan pemukiman baru ini satu sisi sebagai langkah pemerintah untuk peduli kepada kesejahteraan masyarakatnya yang dianulir untuk berpindah ke suatu tempat. Di sisi lain, persoalan ini disebut sebagai bagian dari rekayasa sosial yang'dinobatkan'oleh para ilmuwan sosial.

Pada rekayasa pemukiman baru tersebut, mempunyai berbagai keuntungan pula, mulai dari faktor keamanan bagi korban bencana khususnya dan bagi para yang semula transmigran menjadi faktor kesejahteraan bagi mereka. Akan tetapi ternyata dalam hal ini juga akan memiliki dampak laten (tersembunyi). ${ }^{20}$ Bisa kita sebutkan dalam hal ini faktor lingkungan yang tidak mendukung atau berjauhan dengan aktivitas dari mata pencaharian warga dan berbagai hal lain yang tidak terduga nantinya.

\section{Melacak Studi Terdahulu}

Untuk tujuan studi, segala tinteraksi dan komunikasi yang berlangsung di pemukiman baru (resettlement) menjadi daya tarik tersendiri. Di samping penelitian ini ingin mengetahui secara mendalam tentang tindakakan yang berlangsung di tempat tersebut, peneliti ingin mencoba menyajikan beberapa upaya atau dengan kata lain sebentuk alternatif solusi andaiakan saja keseharian di pemukiman baru mengalami berbagai dilema dan problema. Pada studi yang peneliti lakukan, berupaya mengungkap tindakan yang terjadi pada manusia (mikro) dari para korban tsunami

${ }^{17}$ Opcit..., hal. 75

18 Rika Umar, et al (ed), Kedudukan Peranan Wanita Pedesaan Daerah Istimewa Aceh, (Jakarta: Departemen Pendidikann dan Kebudayaan Proyek Investaris dan Dokumentasi Kebudayaan Daerah, 1986), hal. 12

19 Bahrein T. Sugihen, Perubahan Sosio-Kultural dan Sikap Proses Modernisasi: Suatu Studi Kasus Atas Masyarakat Aceh dalam Transisi, (Banda Aceh: BeunaCitra, 2009), hal 21-22 ${ }^{20}$ Opcit... hal. 81 
Aceh yang hidup di pemukiman baru (resettlement) dengan memiliki latar belakang budaya dan profesi yang berbeda.

Apabila akan menghadirkan kajian literatur di dalam suatu penelitian, sudah barang tentu akan berisi bagian dari tinjauan pustaka, hasil dari penelitian-penelitian terdahulu dan teori-teori yang dianggap sesuai dengan penelitian yang akan dilakukan. Maka dalam hal ini, ada beberapa penelitian terdahulu yang pernah dilakukan dan memiliki kesamaan dengan penelitian ini, baik penelitian yang dilangsungkan secara personal dari karya publikasi perguruan tinggi untuk syarat kelulusan dan penelitian yang sebatas pada tataran menganalisa terhadap kebijakan yang ada. Dengan harapan dari mengangkat penelitian-penelitian terdahulu sebagai bahan pertimbangan dan evaluasi. Berikut hasil dari penelitian terdahulu:

Pertama, penelitian oleh Hildan Mawardi, mahasiswa Universitas Sumatera Utara jurusan Ilmu Kesejahteraan Sosial, tentang"Perubahan Tingkat Kesejahteraan Masyarakat Korban Tsunami di Desa Panteriek Kecamatan Lueng Bata Banda Aceh". Penelitian tersebut bertujuan untuk, mengetahui dan menggambarkan peubahan kesejahteraan sebelum dan setelah terjadinya bendana pada masyarakat korban tsunami di desa Panteriek kecamatan Lueng Bata, kota Banda Aceh

Penelitian yang dilakukan Hildan menggunakan pendekatan kuantitatif, dengan metode analisis secara deskriptif. Mengenai polulasinya, yakni seluruh kepala keluarga korban tsunami yang berjumlah 711 kepala keluarga menetap di desa Panterik. Dan untuk pengambilan sampel dalam penelitian tersebut adalah kepala keluarga yang menjadi korban tsunami yang berada di desa Panteriek. Untuk diketahui bahwa, dari lokasi penelitian yang disebutkan adalah lokasi yang sebelumnya adalah lahan kosong, dan kemudian karenaadanya bantuan dari yayasan Buddha Tsuzchi untuk mendirikan pemukiman baru bagi para korban tsunami yang dominan adalah warga kota Banda Aceh.

Penelitian yang berlangsung pada tahun 2009, di mana waktu tersebut bagi kawasan Aceh secara keseluruhan yang sedang dalam berada dalam masa rehabilitasi dan rekonstruksi berbagai sarana dan infrastruktur. Hildan fokus meneliti kepada hal yang berhubungan dengan tingkat kesejahteraan (kebutuhan Sandang, pangan, papan) masyarakat yang berada di perumahan yang diperhatikan seksama dari sebelum dan setelah bencana gempa bumi tsunami melanda Aceh. Dari hasil penelitian tersebut disimpulkan antara lain:

1. Kondisi sandang responden penelitian sebelum dan sesudah tsunami tidak mengalami perubahan yang berarti. Kondisi ini terjadi karena berbagai faktor di antaranya sudah pulihnya keadaan ekonomi para responden seiring dengan adanya penguatan yang dilakukan oleh berbagai pihak.

2. Kondisi pangan resonden sesudah tsunami juga tidak mengalami peubahan yang berarti. Berdasarkan analisa data tabel para responden, pola konsumsi para responden sudah kembali normal.

3. Kondisi papan para responden penelitian sangat berubah saat sebelum tsunami terjadi dan pasca tsunami terjadi. 100\% responden berstatus menumpang di rumah bantuan yang diberikan oleh yayasan Buddha Tsuzchi.

4. Usaha penemuhan akan pendidikan responden sudah cukup baik. Ini terbukti dari keseriusan mereka memasukkan anak-anak mereka ke sekolah. Dukungan pembangunan sarana dan prasarana sudah sangat baik dan sangat memudahkan masyarakat memenuhi kebutuhan akan pendidikan. 
5. Kondisi pendapatan para responden menurun setelah bencana tsunami, dikarenakan banyaknya kerusukan yang terkena pada sektor mata pencaharian responden sehingga responden harus kembali memulai dari awal.

Kedua, penelitian oleh Isa Anshari Ramadhani, mahasiswa jurusan Psikologi Universitas Airlangga tentang"Kebermaknaan Hidup Bagi Warga Pengungsi Korban Bencana Banjir Lumpur Panas Lapindo Di Tempat Pengungsian Pasar Baru Porong". Adapun tujuan dari penelitian, (1) mendeskripsikan makna hidup yang dimiliki warga korban banjir lumpur Lapindo yang tinggal di tempat pengungsian Pasar Baru Porong. (2), mendeskripsikan faktor-faktor yang mempengauhi warga pengungsi korban banjir lumpur panas Lapindo dalam memaknai hidup.

Penelitian yang dilakukan saudara Isa pada tahun 2009, pasca bencana lumpur Lapindo. Adapun penelitiannya menggunakan pendekatan kualitatif dari metode studi kasus instrinsik dengan pola deskriptif. Unit analisis dalam penelitian ini adalah makna hidup warga yang mengacu pada dimensi sumber makna hidup yang dikemukakan oleh Frankl, yang ditujukan kepada pengungsi korban banjir lumpur Lapindo di tempat pengungsian Pasar Baru Porong. Subjek penelitian adalah warga warga pengungsian yang menjadi korban banjir lumpur Lapindo.

Untuk hasil penelitiannya, antara lain, (1) kebermaknaan hidup warga pengungsi banjir lumpur Lapindo tampak dalam memaknai penderitaan (meaning in suffering) dalam kehidupannya. Perwujudan dari penderitaan diaktualisasika dalam nilai sikap, yaitu ketika warga memilih tetap bertahan di pengungsian pasar baru porong dalam menghadapi penderitaan mereka. Sebagian yang lain mengaktualisasikan dengan sikap lainnya, yaitu tidak ingin menyusahkan orang lain atas penderitaaan yang mereka hadapi. Di samping itu pula, adanya aktualisasi kebermaknaan hidup mereka dalam dimensi makna hidup lainnya, nilai kreatif, dengan tetap berusaha/ beraktivitas dan bekerja ditengah penderitaan yang mereka alami. Dan adanya nilai-nilai pengalaman, dimana faktor keluarga menjadi peran penting buat mereka dan mereka tetap beribadah mendekatkan diri kepada Tuhan yang Maha Esa.

Selanjutnya hasil penelitiannya, (2) terdapat beberapa faktor yang mempengaruhi kebermaknaan hidup warga pengungsi, yaitu, faktor internal, yang terdiri dari nilai-nilai kreatif dan nilai-nilai sikap, yang lebih didominasi dari warga pengungsi pribadi. Dan, faktor eksternal, yang faktor ini berdasarkan nilai-nilai pengalaman warga pengungsi, atau seseorang yang menjadikan mereka mampu untuk memaknai kehidupan mereka, seperti barang (took), pekerjaan, ataupun orang dicintainya.

Ketiga, penelitian oleh Abdulllah Ali, tentang "Strategi Pemukiman Kembali Pengungsi Eks Transmigran di Kabupaten Aceh Jaya". Penelitian dari saudara Abdullah mencoba dengan penganalisaan; menganalisa isu-isu strategis, analisa kegiatan dan juga menganalisis strategis yang dirumuskan di pemukiman kembali eks transmigran di kabupaten Aceh Jaya. Dalam penggunaan pendekatan serupa dengan kualitatif yang bersifat analisis deksriptif, dengan acuan analisa SWOT (Kekuatan, kelemahan, peluang dan tantangan).

Penelitian saudara Abdullah berlangsung pada tahun 2011, pasca tsunami yang melanda kawasan Aceh. Bahagian yang menarik di sini, walaupun mengangkat konsep penelitian dari pemukiman kembali (resettlement), ternyata bukan ditujukan 
kepada korban bencana alam melainkan mereka yang bertempat tinggal di pemukiman adalah eks Transmigran. Adapun kesimpulan dari penelitian ini antara lain,

1. Isu strategis tentang pengungsi eks Transmigran adalah masalah yang harus segera diatasi. Salah satu solusinya adalah pemukiman kembali para pengungsi eks transmigran ke lokasi pemukiman semula.

2. Strategi dalam upaya untuk menenangkan para pengungsi eks transmigran dengan mendapatkan dana dari Pemerintah Pusat melalui APBN (Anggaran Pendapatan Belanja Negara).

3. Tindakan untuk memukimkan kembali para pengungsi eks transmigran adalah mengidentifikasi lokasi pemukiman dan inventarisasi pengungsi, alokasi dana APBN, konstruksi fisik, penggantian para pengungsi, memberdayakan transmigran dan penduduk sekitar, monitoring dan evaluasi kegiatan transmigrasi.

Keempat, penelitian oleh Teguh Budijono, mahasiswa magister manajemen pembangunan kota kampus Intsitus Teknologi Surabaya (ITS) tentang "Kajian Program Resettlement pada Penanganan Darurat bagi Pengungsi (Studi Kasus, Resettlement Pengungsi Timor-Timur di Umaklaran Kabupaten Belu, Provinsi Nusa Tenggara Timur". Dalam penelitiannya, mencermatiaspek prasarana dan sarana dasar perumahan dan permukiman serta perubahan sosial yang terjadi di lokasi resettlement setelah kurun waktu tertentu, sebagai akibat penanganan secara darurat. Adapun penggunaan pendekatan gabungan kuantitatif dan kualitatif , dengan metode analisis deskriptif.

Dari hasil penelitiannya, ditemukan bahwa, pertama, kualitas resttlement $80 \%$ adalah baik, tetapi dilain pihak kualitas ini tidak berhubungan dengan kualitas rumah yang ada, aksesbilitas yang sulit, adanya keinginan untuk kembali kedaerah asal, fasilitas umum dan fasilitas sosial yang ada serta prasarana dan sarana dasar perumahan yang disediakan. Kedua, program pembangunan resettlement secara darurat bagi pengungsi ini pada aspek teknis menghasilkan suatu permukiman yang sudah sesuai dengan standart yang ditetapkan Departemen Kimpraswil/PU, tetapi apabila ditinjau rumah sebagai suatu proses dan proses bermukim kondisi di resettlement ini belum terlihat.

Dan kelima, penelitian Penelitian oleh Nurkhalis berjudul Pemukiman Baru Pasca Tsunami (Studi tentang Proses Adaptasi dan Berkembangannya Identitas KulturalPada Kalangan Warga Perumahan Jacky Chan Desa Neuhen Kecamatan Mesjid Raya, Aceh Besar berusaha mengungkap dengan pendekatan metode kualitatif menggunakan acuan teori Peter Berger dan Thomas Luckmann yakni teori konstruksi sosial, bagaimana proses adaptasi (penyesuaian diri yang berlangsung pada kalangan warga perumahan Jacky Chan (pemukiman baru) dalam interaksi di lingkungan perumahan tersebut dan bagaimana pula proses pembentukan identitas kultural individu dari proses interaksi di kalangan warga perumahan Jacky Chan.

Mengenai perihal adaptasi ada sebagian warga menerima adaptasi di kalangan warga tersebut dan adapula beberapa individu lainnya menolak melakukan adaptasi di lingkungan tersebut. Lebih lanjut dalam proses adaptasi tersebut, terwujud dalam bahasa dan tindakan yang dihadikan dari munculnya institusional (kelembagaan) seperti, adanya praktik keagamaan, seperti Wirid, Tahlilan, Dzikir (dilaksanakan anakanak), kegiatan sosial, seperti gotong royong dan mengunjungi orang yang sakit dan ibu yang melahirkan dan toleransi beragama. Dan selanjutnya terdapat legitimasi 
dalam bentuk himbauan secara lisan serta rasa kepedulian diri (legitimasi non formal) untuk menghadirkan segala aturan yang ada menjadi masuk akal secara subjektif untuk dilakukan.

Dalam proses pembentukan identitas kultural di kalangan warga perumahan Jacky Chan ditemukan bahwasanya adanya tiga jenis identitas di antaranya, identitas Cina-Ambon berafiliasi pembauran yang diperoleh dari sosialisasi Primer 'terpadu' (dominan masih melibatkan sosialisasi primer), selanjutnya identitas Cina-Aceh (terseimbanginya antara identitas kultural Cina dan Aceh dalam individu warga) dan adanya identitas kompatibel (dimana proses ini mengalami proses perubahan bentukan identitas kultural).

\section{PENUTUP}

Dari keseluruhan di atas, bisa kita simpulkan bahwasanya pemukiman dominan berada pada wilayah pedesaan jelas menarik mengamati persoalan kesejahteraan, mata pencaharian, bertahan hidup, perubahan interaksi, dan identitas. Meskipun pemukiman desa mengalami dampak bencana sosial dan bencana alam, maka beberapa isu penting tadi terus menjadi kajian yang seakan tiada bisa dilupakan dan diabaikan. Singkat kata nilai historis desa, serupa dengan warisan, harga diri, dan martabat. Bisa disebut begitu itu.[]

\section{REFERENSI}

Bahrein T. Sugihen. 1996. Sosiologi Pedesaan. Jakarta: RajaGrafindo Persada,

2009. Perubahan Sosio-Kultural dan Sikap Proses Modernisasi: Suatu Studi Kasus Atas Masyarakat Aceh dalam Transisi. Banda Aceh: BeunaCitra,

Budi Fathony. 2009. Pola Pemukiman Masyarakat Madura di pegunungan Buring. Malang: Cita Intrans Selaras,

Irine Hiraswati Gayatri, et al. 2008. Runtuhnya gampong-gampong di Aceh. Jakarta: Pustaka Pelajar

Jefta Leibo \& J. Nasikun. 1986. Sosiologi Pedesaan: Desa kita sebuah Potret Perubahan dalam Berkesinambungan, Mencari suatu Strategi Pembangunan Masyarakat Desa Berparadigma Ganda. Yogyakarta: Andi Offset

Jurnal Siti Muriah, Model Pengembangan Desa-desa Wilayah Perbatasan Secara Institut

Mc Suprapti (ed). 1981. Pola Pemukiman Penduduk Pedesaan Daerah Propinsi D. I. Aceh. Aceh: Departemen Pendidikan dan Kebudayaan Proyek Investaris dan Dokumentasi Kebudayaan Daerah

Rika Umar, et al (ed). 1986. Kedudukan Peranan Wanita Pedesaan Daerah Istimewa Aceh. Jakarta: Departemen Pendidikann dan Kebudayaan Proyek Investaris dan Dokumentasi Kebudayaan Daerah 
Sajogyo \& Pudjiwati Sajogyo. 2005. Sosiologi Pedesaan: Kumpulan Bacaan. Yogyakarta, Gadjah Mada University Press

Sapari Imam Asy'ari. 1993. Sosiologi Kota dan Desa. Surabaya: Usaha Nasional

Soediono M. P. Tjondronegoro. 1999. Keping-keping Sosiologi dari Pedesaaan. Jakarta: Direktorat Jenderal Pendidikan Tinggi Departemen Pendidikan dan Kebudayaan,

Z. Ahmad, et al. 1978. Geografi Budaya Daerah Istimewa Aceh, Proyek Penelitian dan Pencatatan Kebudayaan Daerah. Jakarta: Departemen Pendidikan dan Kebudayaan, 